\title{
ADDING VALUE THROUGH HUMAN RESOURCES: REORIENTING HUMAN RESOURCE MEASUREMENT TO DRIVE BUSINESS PERFORMANCE
}

Arthur K. Yeung and Bob Berman

Building upon the balanced scorecard framework, this article addresses three central issues of human resource (HR) measurement: (1) Do HR practices impact business results? (2) How can HR practices add value to business performance? (3) What HR measures can drive business performance? Using Eastman Kodak as a case study, this article identifies three paths through which HR practices contribute to business performance: (1) by building organizational capabilities; (2) by improving employee satisfaction; and (3) by shaping customer and shareholder satisfaction. Three clusters of measures are proposed: internal operational HR measures, internal strategic HR measures, and external strategic HR measures. (C) 1997 John Wiley \& Sons, Inc.

\section{Introduction}

In our recent survey of 65 senior human resource (HR) executives in California, measurement of HR effectiveness and impact was ranked as the number one topic that HR executives are most interested in exploring. As business competition escalates and corporate resources shrink, all staff functions (e.g., management information systems, finance, human resources, and research and development) are being pressured to demonstrate their value added and to refocus their resources for higher business leverage. Possible outcomes of refocusing staff functions are outsourcing, automation, elimination, and/or downsizing in order to conserve scarce organizational resources. The HR function is no exception to this challenge. What is exceptional about the HR function, however, is that it is less prepared than many other functions (such as finance or management information systems) to quantify its impact on business performance. Conceptual linkages between HR and business performance are not well devel- oped, and existing HR measures are not properly formulated to capture the impact of HR on business performance. As such, efforts to refocus HR may not be well positioned to optimize business performance.

To stimulate discussion and thinking on this timely and vital topic, this article addresses three issues central to the HR-business performance relationship:

1. Do HR practices make a difference in business results?

2. In what ways can HR practices add value to business performance?

3. What are the most appropriate HR measures that drive business performance?

Building upon a balanced scorecard framework (Kaplan \& Norton, 1992, 1993), this article offers a framework highlighting the paths through which HR practices can impact business performance. In general, it can be said that HR practices play three major roles: (1) building critical organizational capa-
What is exceptional about the HR function, however, is that it is less prepared than many other functions (such as finance or management information systems) to quantify its impact on business performance. 
bilities; (2) enhancing employee satisfaction; and (3) improving customer and shareholder satisfaction. Based on the framework, three clusters of HR measures-internal operational measures, internal strategic measures, and external strategic measures-are suggested to help the HR function demonstrate and drive its business contribution. Examples from Eastman Kodak, Sears, and Motorola are used to exemplify some innovative measures in each cluster. Finally, implications for the HR function are discussed.

This article embodies three purposes: (1) to help HR professionals better articulate the value of the HR function; (2) to specify the paths through which HR can contribute to business performance; and (3) to stimulate HR professionals to develop innovative HR measures that can demonstrate the value added of HR practices, on the one hand, and drive business performance on the other. While this article helps frame the HR measurement issue and helps propose a conceptual framework, much more effort will clearly be required to develop the exact $\mathrm{HR}$ measures that address the unique needs of each company.

\section{Does HR Make a Difference in Business Results?}

To many HR functions, this is the fundamental question. Without the conviction that HR does make a difference, HR professionals will not, and cannot, be motivated to develop HR measures that drive business performance. Fortunately, in the last few years, several research studies have reported some important findings regarding the relationships between HR and business performance (Arthur, 1994; Huselid, 1995; MacDuffie \& Krafcik, 1992; Ostroff, 1995; Pfeffer, 1994; U.S. Department of Labor, 1993). Table I summarizes the key findings of these studies in the area of HR-business performance relationships.

Several consistent themes emerge from these exemplary studies of the HR-business performance relationship. First, HR practices definitely make a difference in business results, especially the use of HR practices that build employee commitment. Second, all of these studies examine the HR system as a whole rather than individual HR practices. The synergy and congruence among HR practices have an important impact on business performance. Third, these studies are quite robust as they examine sample firms within an industry [e.g., the auto industry (MacDuffie \& Krafcik, 1992), the steel minimill industry (Arthur, 1994)] and across multiple industries (Pfeffer, 1994), both within a region (Huselid, 1995) and across the nation (Ostroff, 1995).

Building upon the premise that HR practices make a difference in business results, our next challenging task is to offer a conceptual framework that outlines specific ways in which HR practices can exert an impact upon business performance.

\section{How Can HR Practices Impact Business Performance?}

To develop meaningful HR measures, a framework is needed to outline how HR can impact business performance. Based on the experience of Eastman Kodak, this article proposes an integrative framework that builds upon a balanced scorecard framework (Kaplan \& Norton, 1992, 1993) and a strategic HR framework (Ulrich \& Lake, 1990). While the balanced scorecard framework defines what a business should focus on, the strategic HR framework offers specific tools and paths to identify how a firm can leverage its HR practices in order to succeed. In this section, we will first briefly review the balanced scorecard framework, then the strategic HR framework, and finally the integrative framework.

\section{Balanced Scorecard}

The balanced scorecard framework defines what it takes for a company to succeed. Popularized by Robert Kaplan, a Harvard professor, and his associate, David Norton (Kaplan \& Norton, 1992, 1993), it has increasingly been adopted by major companies such as Sears, AT\&T, Eastman Kodak, American Express, and Taco Bell. Simply put, two key premises underlie the concept (Ulrich, 1997). First, for businesses to succeed in the long run, the expectations of three stakeholders-shareholders, customers, and employees-need to be 
TABLE I Summary of Major Research Studies in HR-Organizational Performance Relationships.

\begin{tabular}{lc}
\hline Research Studies & \multicolumn{1}{c}{ Methodology } \\
\hline MacDuffie \& & $\bullet$ Studied 70 automotive \\
Krafcik (1992) & $\begin{array}{l}\text { assembly plants } \\
\text { representing 24 } \\
\text { companies and 17 } \\
\end{array}$ \\
& countries worldwide.
\end{tabular}

U.S. Department of Labor (1993)

Pfeffer (1994)

Arthur (1994)

Huselid (1995)
- Summarized all major research studies regarding the HR-firm performance relationship.

- Identified the five topperforming firms (based on percentage of stock returns) between 1972 and and 1992 and assessed their common

- Conducted a survey research from 30 U.S. steel minimills.

- Utilized both survey research and financial data of 968 firms.
Key Findings

- Manufacturing facilities with "lean production systems" are much higher in both productivity and quality than those with "mass production systems" (Productivity: 22 hours vs. 30 hours in producing a car; Quality 0.5 defects vs. 0.8 defects per 100 vehicles).

- While the HR strategy of a mass production system is used to create a highly specialized and deskilled workforce that supports a large-scale production process, the HR strategy of a lean production system aims to create a skilled, motivated, and flexible workforce that can continuously solve problems.

- The success of a "lean production system" critically depends on such "high-commitment" human resource policies as the decentralization of production responsibilities, broad job classification, multiskilling practices, profit/gain sharing, a reciprocal psychological commitment between firm and employees, employment security, and a reduction of status barrier.

Studies that demonstrate business impact by adopting the following high-performance work practices are summarized:

- Employee involvement in decision making.

- Compensation (profit/gain sharing).

- Training programs.

- Constellation of high-performance work practices.

- Contradictory to traditional strategy literature, these five companies are neither in the right industry (based on Porter's industry structure analysis) nor are they market leaders in these industries (based on Boston Consulting Group's learning curve).

- Instead, these companies share a set of high commitment work practices such as employment security, selectivity in recruiting, high wages, incentive pay, employee ownership, information sharing, participation and empowerment, teams and job redesign, crosstraining, etc.

- Empirically identified two distinct HR configurations: control and commitment systems.

- Control systems aim to reduce direct labor costs, or improve efficiency by enforcing employee compliance with specified rules and procedures and basing employee rewards on some measurable output criteria

- Commitment systems aim to shape desired employee behaviors and attitudes by forging psychological links between organizational and employee goals.

- The mills with commitment systems had higher productivity, lower scrap rates, and lower employee turnover than those with control systems.

- Based on his sample, Huselid found that if firms increase their high-performance work practices by one standard deviation (SD), their turnover would be reduced by $7.05 \%$, productivity increased by $16 \%$. 
TABLE I Continued

Research Studies Methodology Key Findings

Ostroff (1995)
- Conducted a survey research jointly sponsored by Society of Human Resource Management and CCHIncorporated.
- In terms of financial impact, a one-SD increase in highperformance work practices leads to a $\$ 27,044$ increase in sales, a \$18,641 increase in market value, and a $\$ 3,814$ increase in profit.

- Developed an overall HR Quality Index based on the aggregate ratings of all HR activities adopted by a firm.

- Based on the HR Quality Index, firms are grouped into four categories based on their percentile (i.e., bottom 25\%, second 25\%, third 25\%, and top 25\%).

- Firms that score higher in the HR Quality Index consistently outperform firms with a lower index in four financial measures: market/book value ratio, productivity (i.e., sales/employees), market value, and sales. satisfied. While a business may still succeed in the short run if it ignores the expectations of one of the stakeholders, in the long run, its business performance will suffer. Second, as depicted in Figure 1, all three stakeholders are interrelated. Employee attitudes and behaviors impact the level of customer satisfaction and retention. In turn, customer attitudes and behaviors influence shareholder satisfaction and retention. Finally, shareholder satisfaction affects employee satisfaction through bonuses, stock options, or further investment in employee growth and development. If even one of the components breaks down, the system cannot work.

The strength of the balanced scorecard framework is that it provides a simple conceptual and diagnostic tool to ensure that companies utilize the right processes and people to drive customer and business performance.

Figure 1 also lists how Sears, Eastman Kodak, AT\&T, and American Express make use of the balanced scorecard principle but with different terms. In spite of different labels and

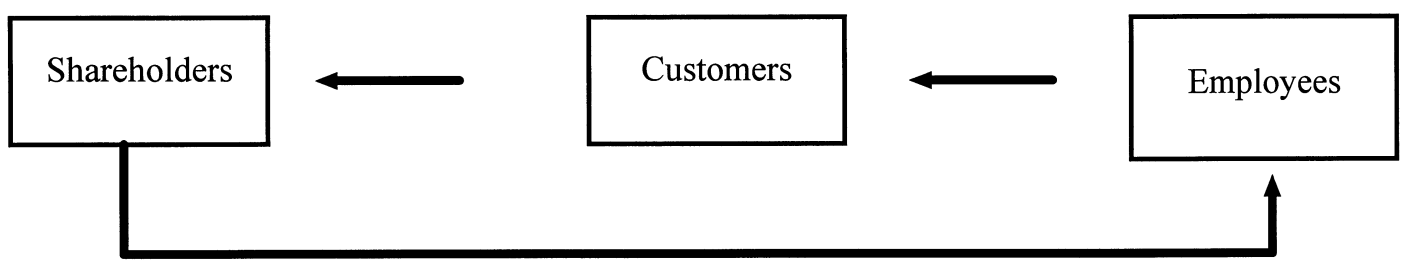

Examples of Balanced Scorecard Applications in Several Companies

\begin{tabular}{||c|c|c|c||}
\hline & Shareholders & Customers & Employees \\
\hline Sears & Compelling Place to Invest & Compelling Place to Shop & Compelling Place to Work \\
\hline Eastman Kodak & Shareholder Satisfaction & Customer Satisfaction & Employee Satisfaction \\
\hline AT\&T & Economic Value-Added & Customer Value-Added & People Value-Added \\
\hline American Express & Shareholder Outcomes & Customer Outcomes & Employee Outcomes \\
\hline
\end{tabular}

FIGURE 1. Framework of a balanced scorecard. 


\section{Compelling Place to Work}

Attitudes about the job

1. I like the kind of work I do.

2. My work gives me a sense of accomplishment.

3. I am proud to say I work at Sears.

4. How does the amount of work you are expected to do influence your overall attitude toward the job?

5. How do your physical working conditions influence your overall attitude toward your job?

6. How does the way you are treated by those who supervise you influence your overall attitude about the job?

Attitudes about the company

7. I feel good about the future of the company.

8. Sears is making the changes necessary to compete effectively.

9. I understand our business strategy.

10. Do you see a connection between the work you do and the company's strategic objectives?

II. Compelling Place to Shop

1. Customer service.

2. Customer recommend products.

3. Customer loyalty.

III. Compelling Place to Invest

1. Revenue growth.

2. Profit contribution margin.

3. Sales per square feet.

4. Inventory turnover.

measurement indices, the logic of the balanced scorecard framework is quite similar in all these companies.

It is intriguing to note that the ultimate power of the balanced scorecard framework does not lie in its conceptual elegance, but in its empirical validity. The following sections examine how the balanced scorecard framework is being validated at Sears and Eastman Kodak.

Sears. As part of its transformation under the new chief executive officer (CEO), Arthur Martinez, Sears believes that "Compelling Place to Work," "Compelling Place to Shop," and "Compelling Place to Invest" are three critical success factors that will in the long run sustain the success of the company. The logic is simple: by creating a "Compelling Place to Work," associates' behaviors will be changed in ways which, in turn, create a "Compelling Place to Shop." As a result, customers are more likely to visit Sears again and thus be retained as steady clientele. Through repeated shopping by loyal customers, Sears can then become a "Compelling Place to Invest," as productivity and financial results both attract and retain shareholders. In order to make this model work, however, Sears understands that all senior managers must be evaluated on the basis of their performance on all three critical success factors, not just on financial results. Their bonuses should also be significantly tied to the measures in these critical factors. Table II lists the measures used to track the performance of managers at Sears.

To ensure that all senior managers "buy into" this model, Sears has undertaken an extensive and comprehensive study to assess whether the model is in fact working as it predicts. In the first and second quarters of 1995 , a Sears task force collected hard data from 800 stores. It collected 300,000 data points and utilized vigorous statistical tools to assess
The Sears example is distinctive as it not only translates "soft" business issues (people) into "hard" (financial results), but also identifies people as the driver of business growth and success. 
the strength of relationship among the three critical success factors: "Compelling Place to Work," "Compelling Place to Shop," and "Compelling Place to Invest." The results, though preliminary, are impressive. Sears reported that for every 5\% improvement in associates' behaviors, customer retention was increased by $1.3 \%$, revenues by $1.04 \%$, and profit by $0.4 \%$.

What does this mean to Sears? It means that if Sears succeeds in improving associates' behaviors by $5 \%$ (e.g., from $50 \%$ to $55 \%$ ), its revenue will be increased by $\$ 300$ million (Sears's current revenue is approximately $\$ 230$ billion)! It is also important to note that this enormous increase in revenue does not require additional head count or payroll, but simply an improvement in employee work environment. Moreover, line managers (not HR) are critical to the creation of such a positive work environment.

The Sears example is distinctive as it not only translates "soft" business issues (people) into "hard" (financial results), but also identifies people as the driver of business growth and success. Based on the above logic and findings, the bonuses of all senior managers at Sears are now tied to a measure called Total Performance Index, of which $25 \%$ of the Index is based on "Compelling Place to Work," 25\% based on "Compelling Place to Shop," and
50\% based on "Compelling Place to Invest." By restructuring the bonus system, Sears' senior managers are encouraged to focus not only on the financial outcomes, but also on the process and capability that contribute to such outcomes.

Eastman Kodak. A similar transformation is under way at Eastman Kodak since George Fisher became CEO. Eastman Kodak, traditionally a technologically driven company which capitalized on its brand name, focused on customer satisfaction through technical innovation to drive shareholder satisfaction. The implicit assumptions were that employee satisfaction could be achieved when the company was financially successful and that employee satisfaction was a byproduct, not a driver, of business success. Results from 1990 to 1993 (please refer to Figure 2), however, revealed that customer satisfaction alone drove neither market value nor employee satisfaction.

While many factors may have contributed to the declining performance of Eastman Kodak from 1990 to 1993, George Fisher decided to restore employee satisfaction as the driver for business success. As he strongly expressed it: "We will never achieve total customer satisfaction without a much higher level of employee satisfaction.... My funda-

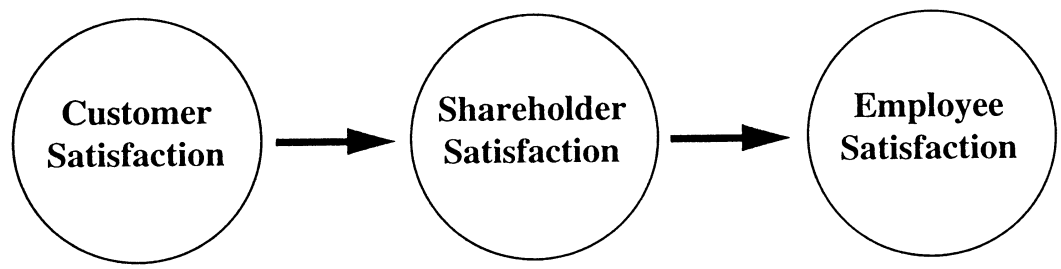

Market Value
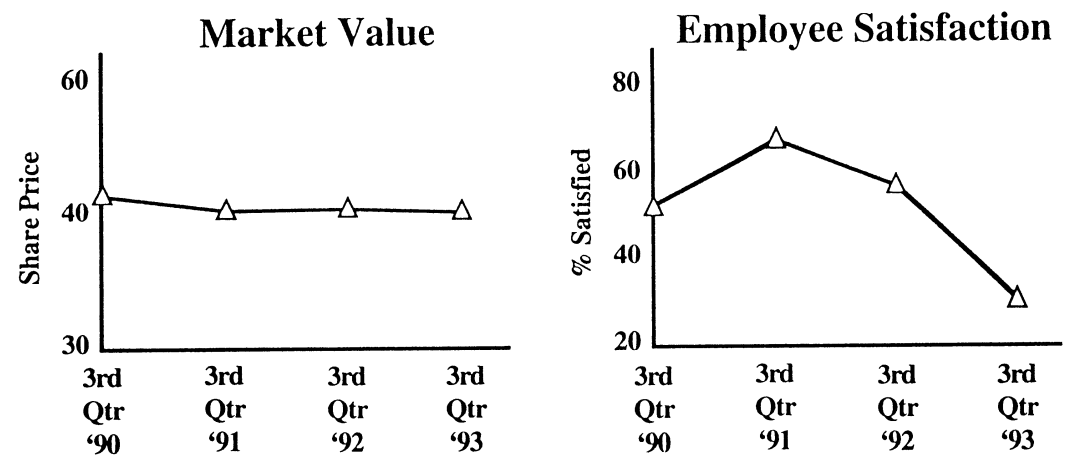

FIGURE 2. Traditional paradigm of employee satisfaction at Eastman Kodak. 

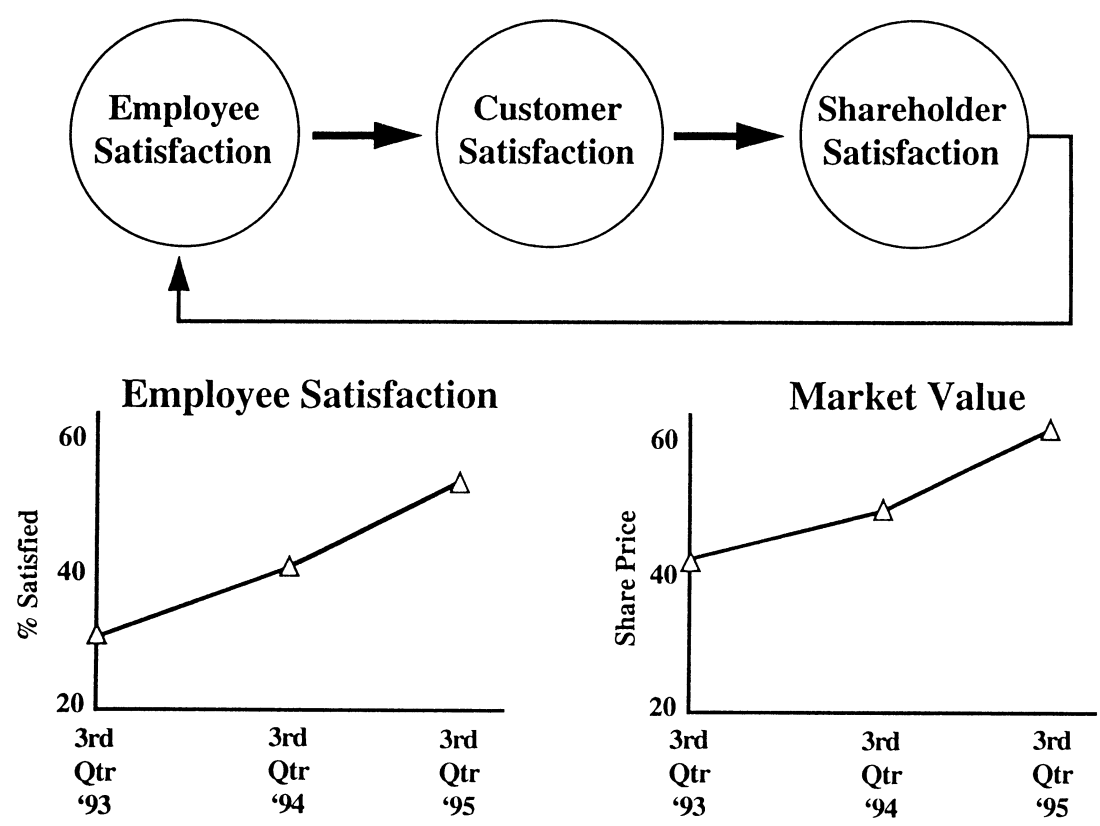

FIGURE 3. The new paradigm of employee satisfaction at Eastman Kodak.

mental responsibility is to make sure this is a strong company and that the employees who exist in this company have a great place to work." As a result, he instituted a new paradigm, using employee satisfaction to drive customer satisfaction and then shareholder satisfaction. Along with other ongoing initiatives, the new paradigm appears to be working. While employee satisfaction has increased about $80 \%$ from 1993 to 1995 , the market value has also increased approximately $90 \%$ in the same period (please refer to Figure 3).

It is naive, however, to claim that the increase in Kodak's market value is completely attributable to the increase in employee satisfaction. Causal relationship is also hard to establish without vigorous statistical analyses and control (as in the case of Sears). Nevertheless, the story of Eastman Kodak is powerful in two ways: (1) it illustrates how CEO Fisher reconceptualizes the relationship among employees, customers, and shareholders to drive business success; and (2) it provides some empirical support of how such a paradigm shift can make a difference in business performance. Eastman Kodak offers another story based on the balanced scorecard principle of how companies use people to drive their business performance.
The balanced scorecard provides a useful business framework that highlights what is required for a company to succeed by meeting the expectations of employees, customers, and shareholders. The next critical questions are: Given the balanced scorecard framework, how can the HR function add value to business success? What kinds of HR practices should be designed to enhance business competitiveness? In the next section, Eastman Kodak's experience will be used to illustrate how HR can contribute to business competitiveness.

\section{Strategic HR Framework}

Like many companies that attempt to align HR practices with business strategy, Eastman Kodak's strategic HR framework involves three components (Ulrich \& Lake, 1990). They are presented below, along with the most pertinent questions a company could ask in its efforts to formulate plans for each component.

1. Business strategy: What is the business strategy of our company? How do we win in the marketplace based on customer buying criteria, competition, 
The Kodak framework lays out three unique ways in which HR can contribute to business success: building organizational capabilities, enhancing employee satisfaction, and shaping customer satisfaction.

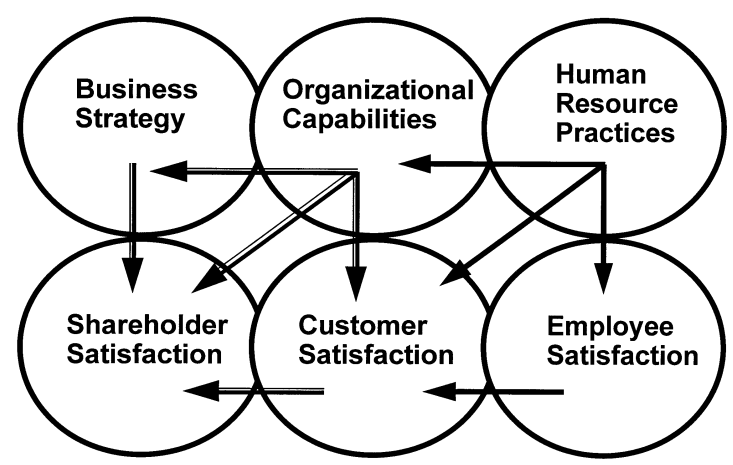

FIGURE 4. Integrative model connecting strategic HR framework to key results areas.

government regulations, supplier situation, etc.?

2. Organizational capabilities: In order to implement the business strategy, what are the critical organizational capabilities we need to develop? Companies often target two or three organizational capabilities that are critical but with which they have not totally succeeded. These capabilities might include competitive shared mindset, speed to market, innovation, etc.

3. Human resource practices: How should HR practices be designed and delivered to build these organizational capabilities? Are our leaders and employees competent, motivated, and empowered to contribute to the fullest extent in the development of these capabilities?

In summary, the strategic HR framework aims to leverage and/or align HR practices to build critical organizational capabilities that enable Eastman Kodak to win in the marketplace.

How can HR practices truly contribute to the critical business success factors as outlined in the balanced scorecard framework? What are the most viable and effective HR measures which can demonstrate the value added of the HR function? To think through the impact of HR practices on business, Eastman Kodak has connected its strategic HR framework to the business framework (see Figure 4).

\section{Integrative Framework}

By integrating the strategic HR framework with the business framework, the interrelationships among the six components can be identified in two linkage chains. In the first chain, HR practice can be conceptualized as key drivers in building organizational capabilities, enhancing employee satisfaction, and more innovatively, shaping customer satisfaction (Ulrich, 1989a; Ulrich \& Lake, 1990). In turn, both organizational capabilities and employee satisfaction can impact customer satisfaction.

In the second chain, organizational capabilities become key drivers which implement business strategy, impact customer satisfaction, and, eventually, contribute to shareholder satisfaction. In addition, both business strategy and customer satisfaction, if properly managed, should increase shareholder satisfaction.

The Kodak framework lays out three unique ways in which HR can contribute to business success: building organizational capabilities, enhancing employee satisfaction, and shaping customer satisfaction. While previous research and case studies have suggested the strategic relevance of HR in each of these three areas, very few researchers have systematically addressed all three contributions:

a. HR-organizational capability linkage: The thesis that HR practices should be aligned to build organizational capabil- 
ity was suggested by Schuler \& Jackson (1987) and Ulrich \& Lake (1990). The argument for this linkage is simple: if companies intend to compete based on specific organizational capabilities (e.g., customer service for Nordstrom, innovativeness for $3 \mathrm{M}$, quality for Motorola), they require a coherent set of $\mathrm{HR}$ practices to influence the mindset and behaviors of their leaders and workforce at all levels.

b. HR-employee satisfaction linkage: The impact of HR practices on employee satisfaction has also been widely publicized through a well-known example of New United Motor Manufacturing Inc. (Pfeffer, 1994). In 1982, the GM Fremont facility was closed due to severe employee problems. When approached by Toyota for a joint venture, GM agreed to reopen the facility in 1984 under a new entity called New United Motor Manufacturing Inc. (NUMMI). Without moving to a new facility, investing heavily in new technology, or hiring a new group of employees $(85 \%$ of NUMMI employees were rehired from the GM Fremont facility with the same UAW hierarchy), NUMMI was able to substantially improve employee satisfaction through radical changes in human resource philosophy and practices. The effects of these HR philosophy and practice changes were dramatic. Between 1982 and 1986, employee absenteeism was reduced from $20 \%$ to $2 \%$; grievances decreased from 2000 per year to two per year; and strikes went from two-four times per year to zero times per year. As a result, productivity was increased by $100 \%$; cost was reduced by $30 \%$; and both quality and consumer satisfaction were enhanced substantially.

c. HR-customer satisfaction linkage: Some pioneering companies are leveraging HR practices to drive customer satisfaction (Ulrich, 1989a). For instance, Baxter Healthcare has offered free consulting and training sessions for its key customers. This has led to two outcomes: (1) key customers become more successful; and (2) stronger relationships with key customers are established. Another positive example of using HR to drive customer satisfaction is Southwest Airline. To ensure that its crew members are customer-focused, the airline has been involving external customers in selecting the crew force. As a result, Southwest's crew members tend to possess attributes that are desired by customers.

The integrative model in Figure 4 is unique in two ways. First, it tightly aligns the HR planning process with the business planning process. For example, while the business framework (i.e., the balanced scorecard) highlights what Eastman Kodak needs to focus on in order to succeed, the strategic HR framework provides specific tools and paths to identify how Eastman Kodak can leverage its HR practices and organizational capabilities to succeed. Thus, the integrative model provides a simple but comprehensive roadmap for a company to think through its strategic focus. Second, the model helps senior line and HR executives rethink the strategic roles within corporations which can be played by HR practices. As human resources clearly have become an important source of sustainable competitive advantage (Pfeffer, 1994; Huselid, 1995), the model explicitly identifies the high value-added contribution of HR practices within corporations.

\section{What Are the New HR Measures that Drive Business Performance?}

If HR practices can impact business success through building up organizational capabilities, improving employee satisfaction, and shaping customer satisfaction, new HR measures should be developed to drive business performance. As succinctly argued by Kaplan \& Norton (1992, p. 71): "What you measure is what you get." Unless HR measures are realigned to drive the activities and behaviors of HR professionals and line managers, HR practices can hardly be expected to demonstrate any impact on the bottom line.

Dramatic changes in HR measures are urgently required to refocus the priorities and re- 
sources of the HR function. Instead of being HR-driven (what makes sense to HR professionals), the next generation of HR measures needs to be business-driven (how HR can impact business success). Instead of being activity-oriented (what and how much we do), new HR measures should be impact-oriented (how much we improve business results). Instead of looking backward (what has happened), innovative HR measures should be forward looking, allowing managers to assess and diagnose the processes and people capabilities that can predict the future success of corporations (Kaplan \& Norton, 1992). Finally, instead of focusing on individual HR practices (the performance of staffing practices, training and development practices, etc.), future HR measurement should focus on the entire HR system, taking into account the synergy existing among all HR practices.

Based on the integrative model in Figure 4, Eastman Kodak has developed three clusters of HR measures:

1. Internal operational measures: How well do we design and deliver our HR practices?

2. Internal strategic measures: How effectively do our HR practices build desired organizational capabilities? How effectively do our HR practices increase employee satisfaction?
3. External strategic measures: How well do our HR practices increase customer and shareholder satisfaction?

Table III lists the possible combination HR measures that can be developed to increase efficiency, quality, and cycle time of HR practices; to build organizational capability; and to enhance employee, customer, and shareholder satisfaction. Examples in each cluster of HR measures are illustrated below.

\section{Cluster 1: Internal Operational Measures}

This cluster of HR measures encompasses traditional HR measures for which the HR function and HR professionals are (and have been in the past) held accountable. It focuses on the efficiency, quality, and speed of delivering HR practices and managing the HR function as a whole.

For HR practices, typical measures include both process measures (such as cycle time, quality, and cost of HR processes/practices) and result measures (such as offer/accept ratios; different levels of training evaluation such as reaction, knowledge, on-the-job behaviors, and business impact) (Cascio, 1987; Fitz-enz, 1984; Ulrich, 1989b). For the HR function, typical evaluative measures include the HR ratio (number of HR professionals to employee population), the percent-

TABLE III Developing New HR Measures that Drive Business Performance.

\begin{tabular}{|c|c|c|c|c|c|c|}
\hline \multirow{2}{*}{$\begin{array}{l}\text { Clusters } \\
\text { of HR } \\
\text { Measures }\end{array}$} & \multicolumn{2}{|c|}{ Internal Operational } & \multicolumn{2}{|c|}{ Internal Strategic } & \multicolumn{2}{|c|}{ External Strategic } \\
\hline & $\begin{array}{l}\text { Process } \\
\text { Measures }\end{array}$ & $\begin{array}{l}\text { Outcome } \\
\text { Measures }\end{array}$ & $\begin{array}{c}\text { Organizational } \\
\text { Capability }\end{array}$ & $\begin{array}{c}\text { Employee } \\
\text { Satisfaction }\end{array}$ & $\begin{array}{l}\text { Customer } \\
\text { Satisfaction }\end{array}$ & $\begin{array}{l}\text { Shareholder } \\
\text { Satisfaction }\end{array}$ \\
\hline \multicolumn{7}{|l|}{ Staffing } \\
\hline \multicolumn{7}{|l|}{$\begin{array}{l}\text { Training/ } \\
\text { Development }\end{array}$} \\
\hline \multicolumn{7}{|l|}{$\begin{array}{l}\text { Performance } \\
\text { appraisal }\end{array}$} \\
\hline \multicolumn{7}{|l|}{$\begin{array}{l}\text { Rewards } \\
\text { system }\end{array}$} \\
\hline \multicolumn{7}{|l|}{$\begin{array}{l}\text { Organization } \\
\text { design }\end{array}$} \\
\hline \multicolumn{7}{|l|}{ Communications } \\
\hline Others & & & & & & \\
\hline
\end{tabular}


age of HR expenses to operating expenses, and the results of the client satisfaction surveys, etc.

In short, these internal operational measures track the activity, cost, and quality level of HR services. When corporations conceptualize the HR function as a cost center, these measures make perfect sense (Wintermantel \& Mattimore, 1997). As the HR function is transformed to be more business oriented (Yeung, Brockbank \& Ulrich, 1994; Wintermantel \& Mattimore, 1997), these traditional HR measures will no longer be adequate and accurate means to assess the performance of new HR roles and activities.

\section{Cluster 2: Internal Strategic Measures}

The internal strategic HR measures assess the effectiveness of HR practices in building organizational capabilities and enhancing employee satisfaction. For instance, at Eastman Kodak three critical organizational capabilities are identified, and specific HR measures are developed to track the progress in these capabilities. The targeted organizational capabilities include:

- Leadership effectiveness (both competency and diversity).

- Workforce competencies (in terms of customer commitment and market focus, working across boundaries, financial excellence, and operational excellence).

- Performance-based culture.

While Eastman Kodak uses 360-degree assessment to measure leadership competency, it also tracks leadership diversity through the race, gender, and nationality composition of its senior and middle managers. Workforce competencies are measured by three aspects of the development process: (1) the percentage of employees with documented development plans to develop required competencies; (2) the number of hours devoted to development; and (3) the results of developmental programs as measured by four levels: reaction and planned action, learning, on-the-job behavior, and business results. Performancebased culture is regularly assessed through the tracking of aligned performance commitments, and employees' surveys which include questions that focus on management accountability for performance, clarity of performance expectations, adequacy of performance feedback, and reward of goal achievement.

To ensure that HR practices are meeting employee needs and expectations, Motorola has developed an index called Individual Dignity Entitlement (Ulrich, 1997). Based on the following six questions, the index directly affects the annual performance review and bonuses of Motorola managers:

1. Meaningful job that contributes to motivation: Do you have a substantive, meaningful job that contributes to the success of Motorola?

2. Behavior and knowledge to be successful: Do you have the on-the-job behaviors and the knowledge base to be successful?

3. Training available to upgrade skills: Has training been identified and been made available to continuously upgrade your skills?

4. Career plan: Do you have a career plan and is it exciting, achievable, and being acted on?

5. Feedback: Have you received candid, positive, or negative feedback within the last 30 days which has been helpful in improving your performance or achieving your career plan?

6. Personal Sensitivity: Is there appropriate sensitivity to your personal circumstances, gender, and cultural heritage so that such issues do not distract from your success?

By tracking these six questions, Motorola can ensure that its HR practices are adding value through a more committed and competent workforce.

Unlike internal operational measures, line managers should be held accountable for the internal strategic measures. As emphasized at Hewlett-Packard, managers are responsible for people management. While HR professionals may design and develop all kinds of $\mathrm{HR}$ practices (such as performance appraisal, reward systems, succession planning, promotion process), the effectiveness of these practices
As the HR function is transformed to be more business oriented (Yeung, Brockbank \& Ulrich, 1994; Wintermantel \& Mattimore, 1997), these traditional HR measures will no longer be adequate and accurate means to assess the performance of new HR roles and activities. 
ultimately relies on implementation by line managers; therefore, line managers, more than HR professionals, should be held accountable for building critical organizational capabilities and enhancing employee satisfaction.

\section{Cluster 3: External Strategic Measures}

The external strategic measures assess the effectiveness of HR practices in satisfying customers and shareholders. The purpose is to use HR practices to drive customer and shareholder satisfaction. Eastman Kodak has experimented with several HR programs to achieve this goal.

The first, a program called Champions for Customer Success, is a customer-oriented program that serves two goals: (1) to create a learning situation that directly connects manufacturing employees with customers (e.g., print shops); and (2) to share best practices and expertise with customers in areas in which they need help, such as reducing paper waste, deploying total quality management (TQM), establishing self-managed teams, etc. By engaging manufacturing people with customers and by helping customers build their capability in those areas, the HR function intends to drive greater customer satisfaction and commitment to Kodak products. In addition, the program serves to build employees' understanding of customers' needs. The simple measures necessary for this program include: (1) incremental sales and earnings as a result of establishing these customer relationships; and (2) change in customer satisfaction and commitment.

Another HR effort that drives customer satisfaction is that of leveraging the executive education process. By inviting senior executives from major customers to attend and share an executive education experience with Kodak executives, Eastman Kodak succeeds in achieving two goals: (1) creating a greater shared mindset with key customers; and (2) enabling Eastman Kodak to meet customer needs more effectively. The performance measure is the degree of change in customer satisfaction and commitment as a result of the shared executive education experience.

Eastman Kodak also has changed a number of processes to create a greater connection between HR practices and shareholder satisfaction. For example, Kodak traditionally had a program called "wage dividend," which was essentially an annual bonus payment that, over time, became a pure entitlement for employees. Every year they could expect $7-8 \%$ of their base pay as a bonus at the end of the year; however, in the last few years, Kodak has changed the plan so that the wage dividend payoff is strictly a function of shareholder satisfaction as measured by return on net assets (RONA) within the corporation. This was supported by a communication process driven by the HR community to help employees understand what RONA is and how it translates to their particular operation within the company. In this way, they could understand what they could do to influence their wage dividend by the end of the year. The HR measure for this program is to determine the change in employee mindset from entitlement to contribution. The purpose is to use the bonus system to drive shareholder value.

Kodak has also used a strategic investment approach to plan and evaluate incentive compensation plans (Boudreau \& Berman, 1991). Using return on investment as a key metric, they have applied tools such as sensitivity analysis and break-even analysis to foster an alignment between HR systems and strategic imperatives from a shareholder perspective. Kodak has taken a similar approach to evaluating the effectiveness of various wellness program initiatives. By collecting a variety of health care experience data from both participants and nonparticipants in these programs, Kodak has been able to assess the financial return it is realizing from these wellness programs.

While these examples highlight how Eastman Kodak is beginning to refocus its HR practices to drive business performance, corporations still need to invest time and resources in developing a set of external strategic HR measures that can systematically align their HR practices with critical business results.

\section{Implications for HR}

By reviewing some recent research studies regarding the HR-business performance relationship, and by building upon the use of the 
balanced scorecard framework in some companies such as Sears and Eastman Kodak, this article has answered the three questions posed at the outset: (1) HR does make a difference in business results; (2) HR practices can contribute to business performance through a multidimensional approach-building organizational capabilities, improving employee satisfaction, and increasing customer and shareholder satisfaction and commitment; and (3) new clusters of HR measures, in addition to the traditional HR measures, should be developed to capture and drive the impact of HR on business performance. After gaining a broad understanding of these issues, several implications for HR function and professionals can be developed.

First, HR matters. With this conviction as the springboard, the challenges which lie ahead for HR professionals are to ensure that: (1) their HR practices are aligned through different paths to add value to business performance; and (2) their HR measures are properly formulated to drive desirable activities and behaviors of both HR professionals and line managers. Because "what you measure is what you get," a new set of HR measures are required to refocus the resources and energies of the HR function.

Second, a framework is a prerequisite to the development of specific HR measures. HR professionals need to understand how HR can contribute to business success before they can decide on HR measures that add business value. The design and development of HR measures typically involves deep thinking, reflection, and discussion in the following three steps:

1. Determine what it takes for the corporation to succeed. What are some important business trends that impact the corporation? What will make or break the corporation in the current and future business environment? Who are the critical stakeholders? How can you, as an HR professional, meet their expectations and needs? What are the scarce resource constraints for the corporation to succeed? These questions should be answered as part of the corporate strategic plan. Based on the balanced scorecard principle, this article suggests that employees, customers, and shareholders are the three interrelated stakeholders who deserve special attention.

2. Understand how HR can add value to the critical success factors. In what ways can HR create sustainable competitive advantage for the corporation? Will it be certain organizational capabilities such as speed, customer service, and innovation? Will it be the accumulation of intellectual capital? Will it be a pool of committed and competent employees? Will it be a group of loyal and committed customers? This article suggests organizational capability, employee satisfaction, and customer satisfaction as three possible avenues through which HR can make an impact. Different corporations may at different times have different priorities. The soul-searching question remains, however: What is the highest valueadded contribution of HR in this corporation? This question should be answered in the strategic HR plan.

3. Design the appropriate HR measures to be aligned with the framework. Once the HR function identifies its unique contribution to the corporation, appropriate measures need to be developed. This article suggests three clusters of HR measures: internal operational measures, internal strategic measures, and external strategic measures. As described in Table III, the HR measures should be developed in a way to reinforce and accomplish the intended contribution of HR. HR professionals, moreover, need to resist the temptation of adopting HR measures in good part because they are easy to collect or track. By all means, internal operational HR measures are the easiest measures to assess; however, it does not mean they are the most important. On the other hand, it is much harder to assess the contribution of HR in internal and external strategic measures, as a host of other factors are also influencing such measures. As "what you measure is what you get," a weak measure on the right issue is better than a strong measure on the wrong issue.
Third, the impact of HR measures on business success is most powerful if a complete process cycle is followed. 
Third, the impact of HR measures on business success is most powerful if a complete process cycle is followed. While the development of appropriate HR measures is a vital first step, the implementation of the measurement process is equally important. The full potential of HR measurement cannot be fully utilized until the following steps are taken:

1. Accurate data on desirable HR measures are collected on an ongoing and timely basis. It is important to ensure that critical data are captured at the right moment when HR programs or activities are designed and delivered.

2. HR measures are analyzed and feedback is presented in a timely manner. One common fallacy for many companies is to collect quantities of data, analyze them, and file them on a shelf. To drive behaviors and performance, all HR measures need to be widely disseminated to the right audience (both HR professional and line managers) for feedback purposes.

3. The purpose of HR measures is to stimulate change and improvement. HR professionals and line managers need to use the findings to create an open forum to diagnose/solve problems and to improve organizational capabilities. The discussion and action planning which result from the HR measures are much more valuable than the results of the measures themselves.
4. Both HR and line managers are accountable for HR measures. Depending on their areas of responsibility, both HR managers and line managers should be assessed based on the HR measures. While HR professionals should be accountable for the internal operational HR measures (e.g., cost and efficiency of delivering HR services), line managers (like those in Sears and Motorola) should also be accountable for their approaches to managing employees, to building organizational capability, and to enhancing customer satisfaction. The results of HR measures should constitute part of their performance review and bonus scheme.

Without moving through such a complete cycle, HR measures cannot drive the desirable behaviors of line managers in utilizing employee contribution. As a result, the linkages between HR measures and business performance will be weakened.

When faced with the challenges of demonstrating its value added, the HR function has to carefully think through its value proposition and its impact on business performance. By developing the right measures, HR can clearly demonstrate its strategic relevance within corporations, firmly establish its invaluable status as a strategic business partner, and substantially contribute to business success.

Arthur K. Yeung is the Executive Director (Asia-Pacific) of the University of Michigan Business School and a faculty member at the Michigan Executive Education Center. His areas of specialization include HR process reengineering, strategic HR management, AsiaPacific management practices, and organizational learning. He is an Associate Editor of Human Resource Management and has published more than 15 articles in leading HR journals. Dr. Yeung is involved in leadership development programs for numerous corporations, including ABB, Philips, Carrier, Hewlett-Packard, ICI, and Allied Signal Inc.

Robert Berman is Director, Human Resources, and Vice President of the Consumer Imaging business of Eastman Kodak Company. He joined Kodak in 1982, and has served in a wide variety of assignments within Kodak's HR community. His current responsibilities include leadership in the delivery of integrated strategic and operational HR services to Kodak's global, $\$ 7$ billion consumer products business. He is leading the organizational and individual capability strategies underpinning the growth strategies of the Consumer Imaging business. Mr. Berman has a B.S. in Business from the University of Minnesota and a Master of Industrial and Labor Relations from the New York State School of Industrial and Labor Relations at Cornell University. 


\section{REFERENCES}

Arthur, J. (1994). Effects of human resource systems on manufacturing performance and turnover. Academy of Management Journal, 37, 670-687.

Boudreau, J.W. \& Berman, R.L. (1991). Using performance measurement to evaluate strategic human resource decisions: Kodak's experience with profit sharing. Human Resource Management, Fall, 393-410.

Cascio, W. (1987). Costing human resources: The financial impact of behavior in organizations. New York: Van Nostrand Reinhold.

Fitz-enz, J. (1984). How to measure human resources management. New York: McGraw-Hill.

Huselid, M. (1995). The impact of human resource management practices on turnover, productivity, and corporate financial performance. Academy of Management Journal, 38, 635-672.

Kaplan, R.S. \& Norton, D.P. (1992). The balanced scorecard-Measures that drive performance. Harvard Business Review, January-February, 71-79.

Kaplan, R.S. \& Norton, D.P. (1993). Putting the balanced scorecard to work. Harvard Business Review, September-October, 134-147.

MacDuffie, J.P. \& Krafcik, J.F. (1992). Integrating technology and human resources for high-performance manufacturing: Evidence from the international auto industry. In Kochan, T. \& Useem, M. (eds.), Transforming organizations. New York: Oxford University Press.

Ostroff, C. (1995). Human resource management:
Ideas and trends in personnel, June 21, Issue number 356, CCH Incorporated.

Pfeffer, J. (1994). Competitive advantage through people: Unleashing the power of the work force. Boston, MA: Harvard Business School Press.

Schuler, R. \& Jackson, S. (1987). Linking competitive strategies with human resource management practices. The Academy of Management Executive, 1, 207-219.

Ulrich, D. (1989a). Tie the corporate knot: Gaining complete customer commitment. Sloan Management Review, Summer, 19-28.

Ulrich, D. (1989b). Assessing human resource effectiveness: Stakeholder, index, and relationship approaches. Human Resource Planning, 12, 301-315.

Ulrich, D. (1997). Measuring human resources: An overview of practice and a prescription for results. Human Resource Management, this issue.

Ulrich, D. \& Lake, D. (1990). Organizational capability: Competing from the inside/out. New York: Wiley.

U.S. Department of Labor (1993). High performance work practices and firm performance, August.

Wintermantel, R. \& Mattimore, K. (1997). In the changing world of human resources: Matching measures to mission. Human Resource Management, this issue.

Yeung, A., Brockbank, W., \& Ulrich, D. (1994). Lower cost, higher value: HR function in transformation. Human Resource Planning, 17, 1-16.

\section{ENDNOTE}

We acknowledge the financial support of the California Strategic Human Resource Partnership in sponsoring the conference, "Measuring HR Effectiveness and Impact," which brought together a group of thought lead- ers and leading practitioners in this topic. Special thanks to Dave Ulrich at the University of Michigan, Rick Quinn at Sears, and Tapas Sen at AT\&T who helped frame the ideas in this article. 
